\title{
Economies of scale and scope in Australian superannuation (pension) funds
}

\author{
Helen Higgs and Andrew C. Worthington
}

are researchers in the Department of Accounting, Finance and Economics at Griffith University, Australia. Their research interests include the drivers of structural change in the Australian superannuation industry.

\begin{abstract}
This article provides estimates of economies of scale and scope for 200 large Australian superannuation (pension) funds using a multiple-output cost function. We separately define costs in terms of investment expenses-including investment, custodian, and asset management fees-and operating expenses-comprising management, administration, actuarial, director and trustee fees/charges. The four investment outputs are cash flow-adjusted net assets, the number of investment options, the proportion of total assets in the default strategy, and the five-year rate of return for investment costs, while the four operating outputs are cash flow-adjusted net assets, the number of members, net contribution flows, and net rollovers for operating costs. We find that economies of scale hold up to at least 300 percent of current mean fund output in both investment and operating costs. There is little evidence that economies of scope prevail, generally reflected in the proclivity for many superannuation funds to contract out aspects of both investments and operations.
\end{abstract}

Keywords: economies of scale, economies of scope, cost efficiency, superannuation (pension) funds

\section{Introduction}

Australia's superannuation system [comprising a compulsory employer-funded superannuation (retirement income) system supplemented by a narrowly focused (age, means and income tested) public pension] continues to grow apace with superannuation savings forecast to increase from $\$ 1.1$ trillion (90\% of GDP) today to $\$ 6.1$ trillion (130\% of GDP) by 2035 . The profile and structure of the superannuation industry has also changed rapidly, with consolidation projected to cause the number of large funds to fall from 447 today (4,734 in 1996) to 74 in 2035, with the largest fund to increase from $\$ 41.5$ billion today to $\$ 350$ billion in 2035 . ${ }^{1}$ However, accompanying these dramatic changes has been disquiet about several limitations of the present system in terms of efficiency (that it operates in the most cost effective manner and in the best interests of members) and operations (that returns to members are maximized, including through minimizing costs).

Reporting in June 2010, the Review of the Governance, Efficiency, Structure, and Operation of Australia's Superannuation System (Cooper Review) made a large number of recommendations. These include the substantial benefits for members of increased scale in the superannuation industry and the desirability of the Australian Prudential Regulation Authority (APRA) in overseeing and promoting the efficiency of the superannuation system. They also include the proposed role of SuperStream (a package of measures aimed at reforming back-office operations in terms of the increased use of technology, uniform data standards, tax file identification, and straight-through processing of transactions) and MySuper (a simple product designed for the majority of members) in lowering overall costs.

Clearly, a major focus in these and future developments has been and will be the level of investment and operating (administration) costs, particularly their interaction with the scale (the size of production) and scope (the diversity of production) of superannuation funds. Unfortunately, and outside the Cooper Review's partial evidence, there is relatively little work on the role of economies

Correspondence: Professor Andrew C. Worthington Department of Accounting, Finance and Economics, Griffith University, 170 Kessels Road, Nathan, Queensland 4111, Australia E-mail: a.worthington@griffith.edu.au 
of scale and scope in improving the level of cost efficiency in superannuation funds. In fact, just three studies broadly relate to the objective of this paper to estimate economies of scale and scope in Australian superannuation funds.

First, Ang and Wuh Lin ${ }^{2}$ employ cost functions to estimate economies of scale and scope, but for US mutual funds. Their emphasis is on the parameter estimates for different fund characteristics (including asset allocation and investment strategy) with the findings indicating strong economies of scale in operating expenses, but only weak evidence of economies of scope in multiproduct funds. Second, Malhotra, Marisetty, Vijaya and Ariff ${ }^{3}$ estimate a translog cost function for retail superannuation funds in Australia in 1999/2000. Putting aside that this analysis is now rather dated, the emphasis lies with estimates of cost elasticities at the mean and not economies of scale at different levels of output. There is no attention to economies of scope. Finally, Bikker and de Dreu ${ }^{4,5}$ formulate models of investment and operating costs for Dutch pension funds, but as with Malhotra, Marisetty, Vijaya and Ariff ${ }^{3}$, there is no attempt to estimate economies of scope nor discuss scale and scope efficiencies at different levels of observed output. Nevertheless, it is in the spirit of the latter that we frame our analysis. In so doing, we complement the finding of existing studies of costs in superannuation (pension) funds in the US ${ }^{6,7,8,9}$, Australia ${ }^{10,11,12}$, Ireland ${ }^{13}$ and the $\mathrm{UK}^{14}$.

In the rest of the article, we first briefly discuss investment and operating costs in superannuation funds. We then describe the specification of superannuation fund costs and outputs used in the analysis. Afterwards, we describe the cost function used to estimate the economies of scale and scope and present the results. We end the article with a brief conclusion.

\section{Economies of scale and scope in superannuation funds}

In general, we can divide the overall costs required to operate a superannuation fund into two areas: investment costs and operating (or administration) costs. To start with, investment-related costs are expenses required to make and undertake investment decisions and, according to the Cooper Review ${ }^{1}$, are quite properly related to the assets under management, principally investment, custodian, and asset management fees. While we expect the quantum of these costs to increase with assets under management, they will necessarily vary with whether the assets are actively or passively managed, the nature of the underlying distribution of assets, and the extent to which the trustee has decided to in invest in alternative and illiquid assets.

By comparison, operating costs in superannuation funds largely reflect the transaction-based needs of fund members across a wide range of services, including customer interface (call centres, websites, mailrooms, marketing), back office processing (new members, benefit payments, contribution uploads, compliance, audit and reporting), and record-keeping systems (information technology, member records, transactions, and investment support). Importantly, external parties (such as custodian services) almost universally handle some of these services, whereas others are along a spectrum of in-house and external third-party providers. Equally importantly, while most of these costs positively relate to fund membership, they have the propensity to decline with average account size.

In terms of both theory and the goal of maximising member benefits net of costs, a possible long-run cost objective for a superannuation fund is to be in a position to produce the desired output (or outputs) at the lowest possible cost (or cost minimisation). Based on the above discussion, the principal outputs for most superannuation funds would appear to be assets (for investment costs) and members (for operating costs). Among other things, this means adjusting the scale of production to the most appropriate size. Sometimes dividing the production process into smaller more specialized production units can result in economies, as evidenced by the allocation of some superannuation funds tasks across divisions or departments. On other occasions, enlarging the scale of production can achieve lower unit costs. Through this process, superannuation funds overcome indivisibilities in factor inputs, avoid the costs of a lack of capacity, and gain access to economies in 
the fixed costs of production including marketing and administration (including human resources and information technology).

Once multiple products arise, the presence or absence of complementarities between outputs may provide cost advantages in that a single fund producing a given level of output for a number of product or product dimensions may spend less than a combination of several specialised funds. With production in superannuation funds, the production process typically comprises multiproduct attributes because it produces multiple products (different investment options, member services, and returns) through the sharing and joint utilisation of inputs including investing management and administrative labour, custodian services, information technology, human resources, and so on.

\section{Specification of outputs and costs}

For our analysis, we use data consisting of fund-level observations of Australia's 200 largest superannuation funds. We obtain the data from APRA. Unfortunately, only a single cross-section of date was available in 2011. Stochastic cost functions typically regress costs (here investment and operating costs) on the quantity and price of the factor inputs used in production (typically capital and labour) and the outputs produced. Unfortunately, the limited data released by APRA does not permit full specification of the prices and quantities of the factor inputs. As this data is not available, it amounts to the assumption that input prices are constant across the superannuation industry and so the quantity of factor inputs employed in production is proportional to the quantity of investment expenses. Fortunately, this is a realistic assumption in that Australian superannuation funds are arguably price-takers operating in highly competitive global factor markets.

\section{< TABLE 1 HERE >}

We specify four outputs each for the investment and operating functions of superannuation funds. Table 1 provides selected descriptive statistics. For investment costs these are: cash flow adjusted assets (CAS) (in \$ millions), the number of investment options (IOP), the percentage of funds in defined benefits (DEF), and the percentage five-year average return (FIV). On this basis, as the number of investment options increases, so too will the costs associated with management, while a larger proportion of members in a defined benefit fund will tend to place downward pressure on investment costs associated with a relatively more conservative strategy. Lastly, we expect that higher investment returns will ultimately only result from increased investment expenses at the fund level, even if only for the fact that management securing higher returns will demand a premium for its services.

Turning to operating costs, the four outputs are cash flow-adjusted assets (CAS) (in \$ millions), the number of members (MEM), net contributions (CNT) (in \$ millions) and net rollovers (RLL) (also in \$ millions). The principal argument here is that operating costs mostly relate to transaction-related services within the fund and that these will primarily vary with the number of fund members. However, they will also vary with the average account size and the frequency and magnitude of member transactions with the fund in terms of contributions and rollovers.

\section{Model specification}

We use a cost function to estimate economies of scale and scope in Australian superannuation funds. The basic assumption is that superannuation funds seek to minimise costs at some chosen level of output. A cost function that allows the economies of scale to vary with the different levels of output is:

$$
C=\alpha_{0}+\sum_{i=1}^{4} \alpha_{i} y_{i}+1 / 2 \sum_{i=1}^{4} \beta_{i}\left(y_{i}\right)^{2}+\sum_{\substack{i, j=1 \\ i \neq j}}^{4} \delta_{i j} y_{i} y_{j}+\varepsilon_{i}
$$


where $\alpha_{0}$ is the fixed cost term, $\alpha_{i}(i=1,2,3,4)$ are the slope coefficients of the linear term, $\beta_{i}(i=$ $1,2,3,4)$ are the slope coefficients of the quadratic terms, $\delta_{i j}(i=1,2,3,4, j=1,2,3,4$ and $i \neq j)$, are the slope coefficients of the cross-product terms, $C$ is the of the total operating costs of each superannuation fund (in $\$ 000$ ) and $y_{1}$ to $y_{4}$ represent the outputs.

The cost function in (1) allows the estimation of the economies of scale and scope. These are ray economies of scale, product-specific economies of scale, and product-specific economies of scope. Under ray economies of scale, we assume the composition of each superannuation fund's output remains fixed while the aggregate size of output varies. This provides a measure of scale analogous to the single output case where ray economies (diseconomies) of scale exist if the measure is greater (less) than unity. Product specific economies of scale, however, allow one output to vary, while others are constant. Product-specific economies (diseconomies) of scale then exist if the measure is greater (less) than unity. Finally, product-specific economies of scope measure whether the cost of producing the outputs jointly is less than the costs of producing them separately. A value greater than or equal to zero thus indicates that cost advantages accrue through the joint production of outputs.

The method for calculating these measures is as follows. First, the average incremental cost, $\operatorname{AIC}\left(y_{i}\right)$ for producing output $y_{i}$ is defined as:

$$
\operatorname{AIC}\left(y_{i}\right)=\frac{C(y)-C\left(y_{N-i}\right)}{y_{i}} \quad i=1,2,3,4
$$

where $C(y)$ is the total cost of producing the outputs and $C\left(y_{N-1}\right)$ is the total cost of producing zero units of the $i$ th output. In the case of a single product, we measure the economies of scale using the average incremental cost divided by the marginal cost. The product-specific economies of scale for $y_{i}, E\left(y_{i}\right)$ are specified as:

$$
E\left(y_{i}\right)=\frac{A I C\left(y_{i}\right)}{M C\left(y_{i}\right)}
$$

where $M C\left(y_{i}\right)=\partial C / \partial y_{i}$ is the marginal cost of producing $y_{i}$ units of output. Ray economies of scale exist when the quantities of the product increase proportionately:

$$
E(R A Y)=\frac{C(y)}{\sum_{i=1}^{4} y_{i} \times M C\left(y_{i}\right)}
$$

If $E\left(y_{i}\right)$ or $E(R A Y)$ is greater than one (less) than one then economies of scale (diseconomies of scale) exists for output $y_{i}$. Second, we can divide economies of scope into global economies of scope $(G E S)$ and product-specific economies of scope $(P E S)$ and these are:

$$
G E S\left(y_{i}\right)=\frac{\sum_{i=1}^{4} C\left(y_{i}\right)-C(y)}{C(y)}
$$

The product-specific economies of scope are:

$$
\operatorname{PES}\left(y_{i}\right)=\frac{C\left(y_{i}\right)+C\left(y_{N-i}\right)-C(y)}{C(y)}
$$

\section{Empirical results}

Table 2 presents the estimated coefficients, standard errors, and $p$-values of the investment and operating cost functions. The $\mathrm{R}^{2}$ for the investment cost function reported on the left-hand side of 
Table 2 is 0.6470 while that for the operating cost function on the right-hand side is 0.7776 . We test the null hypotheses of no output effects jointly in addition with various tests of no linear, quadratic and output cross-product effects with Chi-squared test statistics. We reject all hypotheses at the one percent level of significance, thus suggesting that all explanatory variables should jointly be included in estimating the investment and operating cost functions for Australian superannuation funds.

\section{< TABLE 2 HERE >}

We use the estimates in Table 2 to calculate the marginal costs (MC) and average incremental costs (AIC) for each of the four superannuation fund outputs (CAS, IOP, DEF and FIV for investment costs and CAS, MEM, CNT and RLL for operating costs). As shown in Table 3, we do this for levels of mean output running from $50 \%$ to $300 \%$ (i.e. $100 \%$ is the mean output in the sample data). The mean values are $\$ 3,435$ for CAS, 97.14 for IOP, $51.34 \%$ for DEF, $3.37 \%$ for FIV, 153.93 for MEM, $\$ 193.47$ for CNT and $\$ 22.16$ for RLL. Consider the marginal costs of investment on the left-hand side of Table 3 in the lower panel. As shown, investment costs decline continuously as output (as measured by cash flow adjusted assets) increases from 50\% to $300 \%$ of the current mean output of Australia's 200 largest superannuation funds. This is also the case for the number of investment options (IOP) suggesting that larger funds with more investment options find it increasingly less costly on a marginal basis. However, marginal costs increase as the share of defined benefits (DEF) in the fund and the five-year return (FIV) increases, suggesting that better investment performance comes at a price to net benefits. A similar picture emerges with the operating cost function on the right-hand side of Table 3. As shown, the main driver of operating costs at higher levels of output appears to be size of the fund in terms of cash flow adjusted assets (CAS) and the amount of fund rollovers (RLL). At all but the lowest level of mean output, the number of members (MEM) and the levels of contributions (CNT) have only a small impact on operating costs, suggesting that most operating costs are fairly small per member and dollar value of contributions once some minimum fund size is attained.

\section{< TABLE 3 HERE>}

The upper panel of Table 4 presents the product-specific (E) and ray (RAY) economies of scale for investment and operating costs. As defined, the point estimates represent the ray economies (diseconomies) of scale: if the point estimate is greater than unity, then ray economies of scale exist across the outputs. As shown, ray economies (the proportional augmentation of output holding composition constant) exist from $50 \%$ to $300 \%$ of the mean output over the sample period for both investment and operating expenses. This suggests that the sector as a whole is currently experiencing economies of scale and there is a clear incentive to expand the production of all outputs to exploit existing potential scale economies. However, while the ray economies for investment costs are continuously increasing at an increasing rate those for operating costs are increasing at a decreasing rate. Ultimately, at some level above $300 \%$ of the current mean output, diseconomies of scale will influence operating costs in Australia's superannuation funds.

\section{$<$ TABLE 4 HERE $>$}

The upper panel in Table 4 also includes the product-specific economies of scale. These are the scale economies that exist were an output increased in isolation. As shown, for investment costs there are product-specific economies of scale from $150 \%$ to $300 \%$ of current mean output for CAS, from $100 \%$ to $300 \%$ for IOP and from $250 \%$ to $300 \%$ for FIV. This complements evidence from the previous table that the main drivers of scale economies in superannuation funds are increasing the level of assets under management and the number of investment options. Turning to operating costs, the product-specific economies of scale only operate for relatively narrow bands at low levels of output. This suggests that scale economies in operating costs can only be realised when increasing all transaction-related activities in proportion within the same fund. 
Unlike many other industries, production in Australian superannuation funds does not typically involve full joint production of the various investment and operating outputs given the tendency for funds to choose various combinations of contracted out and in-house provision of both investments and operations. This would appear justified in the lower panel of Table 4 where there are global economies of scope (GES) only for operating costs at high levels of mean output (150\% to $300 \%$ ). There would appear to be no economies of scope possible in investments overall, and only some product-specific economies of scope for the IOP, DEF and FIV at extremely low levels of output. Overall, this would suggest there is little incentive for superannuation funds to undertake all of their various investment and operating activities in-house once the fund has reached just 50\% to $75 \%$ of the current level of mean output. Beyond this point, there are certainly strong economies of scale in both investments and operations, and thus an incentive for the fund to grow larger through increasing assets under management and the number of members through growth or fund consolidation, but little evidence of economies of scope. Hence, it is highly cost-effective for large superannuation funds to contract-out many of their investment and operating activities.

\section{Conclusion}

This article discusses the results of a study of economies of scale and scope in Australian superannuation fund. The main findings are as follows. First, there is evidence of ray economies of scale (assuming the composition of outputs remains unchanged) up to at least $300 \%$ of current mean output in both investments and operations. After this point, there is some evidence that diseconomies of scale in operations may arise and so there is little incentive for superannuation funds to expand output far beyond that level. However, the economies of scale in investment costs increase at an increasing rate up to $300 \%$ of the current level of output and this suggests that diseconomies in investment costs (if they do exist) will only apply at very much higher levels of output than currently found in the Australian superannuation fund industry. Second, in contrast the evidence for economies for scope is very weak, with global economies of scope only found in operations and then only at very high levels of output. This suggests that only the largest funds will benefit in cost terms from full in-house production of administrative services and that for the typical superannuation fund there are substantial cost savings in contracting-out many administrative tasks and nearly all investment activities (or at least, there are no significant cost savings for in-house production).

\section{References}

1 Review of the Governance, Efficiency, Structure and Operation of Australia's Superannuation System (Cooper Review) (2010), Super System Review, Final Report - Part One: Overview and Recommendations, Commonwealth of Australia, Canberra, available at: http://www.supersystemreview.gov.au.

2 Ang, J.S. and Wuh Lin, J. (2001) A fundamental approach to estimating economies of scale and scope of financial products: The case of mutual funds. Review of Quantitative Finance and Accounting 16: 205-222.

3 Malhotra, D.K.K., Marisetty, Vijaya B. and Ariff, M. (2001) Economics of Scale in the Retail Superannuation Funds in Australia, EFMA 2002 London Meetings. Available at SSRN: http://ssrn.com/abstract=314395.

4 Bikker, J. and de Dreu, J. (2006) Pension fund efficiency: The impact of scale, governance and plan design, DNB Working Paper, No. 109. Available at: http://ideas.repec.org/p/dnb/dnbwpp/109.html.

5 Bikker, J. and De Dreu, J. (2009) Operating costs of pension funds: The impact of scale, governance and plan design. Journal of Pensions, Economics, and Finance 8(1): 863-889.

6 Mitchell, O.S. and Andrews, E.S. (1981) Scale economies in private multi-employer pension systems. Industrial and Labour Relations Review 34(4): 522-530.

7 Mitchell, O.S. (1998) Administrative costs of public and private pension plans. In: M. Feldstein (ed.) Privatizing Social Security, Chicago: University of Chicago Press, pp. 403-456.

8 Ghilarducci, T. and Terry, K. (1999) Scale economies in union pension plan administration: 1981-1993. Industrial Relations 38(1): 11-17.

9 Barber, B., Odean, T. and Zheng, L. (2005) Out of sight, out of mind: The effects of expenses on mutual fund flows. Journal of Business 78(6): 2095-2119. 
10 Clare, R. (2001) Are administration and investment costs in the Australian superannuation industry too high? Association of Superannuation Funds of Australia, available at: http://www.superannuation.asn.au.

11 Bateman, H. (2001) Disclosure of superannuation fees and charges, Centre for Pensions and Superannuation, Discussion Paper No. 03/04, available at: http://www.superannuation.asn.au.

12 Bateman, H. and Mitchell, O.S. (2004) New evidence on pension plan design and administrative expenses: the Australian experience. Journal of Pension Economics and Finance 3: 63-76.

13 Mahon, A. (2006) Irish occupational pensions: An overview and analysis of scale economies. Presentation to the Irish Association of Pension Funds, available at http://repository.wit.ie/426/.

14 Audit Commission (2006) Efficiency challenge: Cost of administering local government pension funds in London, Local Government National Report, available at: http://www.audit-commission.gov.uk/. 
Table 1: Selected descriptive statistics

\begin{tabular}{|c|c|c|c|c|c|c|c|}
\hline & $\begin{array}{c}\text { Cash flow- } \\
\text { adjusted } \\
\text { assets (\$ mil.) } \\
\text { (CAS) }\end{array}$ & $\begin{array}{c}\text { Number of } \\
\text { investment } \\
\text { options (IOP) }\end{array}$ & $\begin{array}{l}\text { Percentage of } \\
\text { funds in } \\
\text { defined benefit } \\
\text { (\%) (DEF) }\end{array}$ & $\begin{array}{c}\text { Five-year } \\
\text { return (\%) } \\
\text { (FIV) }\end{array}$ & $\begin{array}{c}\text { Number of } \\
\text { members } \\
\text { (MEM) }\end{array}$ & $\begin{array}{c}\text { Net } \\
\text { contributions } \\
\text { (\$ mil.) }(\mathrm{CNT})\end{array}$ & $\begin{array}{l}\text { Net rollovers } \\
\text { (\$ mil.) (RLL) }\end{array}$ \\
\hline Mean & 3435.4930 & 97.1421 & 51.3484 & 3.3775 & 153.9352 & 193.4730 & 22.1628 \\
\hline Maximum & 43584.5300 & 2752.0000 & 100.0000 & 9.6400 & 2642.9670 & 2911.0470 & 1744.0210 \\
\hline Minimum & 176.4190 & 1.0000 & 0.0000 & -0.4400 & 0.9520 & -639.7790 & -514.9150 \\
\hline Std. Dev. & 6145.1620 & 333.8608 & 33.7765 & 1.3430 & 353.2147 & 497.1930 & 247.2119 \\
\hline Kurtosis & 18.5560 & 43.4502 & 1.5539 & 4.8195 & 22.8917 & 14.9612 & 22.8568 \\
\hline
\end{tabular}

Table 2: Estimated cost function

\begin{tabular}{|c|c|c|c|c|c|c|c|c|c|}
\hline \multicolumn{5}{|c|}{ Investment costs } & \multicolumn{5}{|c|}{ Operating costs } \\
\hline Variable & & Coefficient & Std. Error & Prob. & Variable & & Coefficient & Std. Error & Prob. \\
\hline $\mathrm{C}$ & $\alpha_{0}$ & 7785.6090 & 4383.4570 & 0.0774 & $\mathrm{C}$ & $\alpha_{0}$ & 192.6253 & 1561.3220 & 0.9020 \\
\hline CAS & $\alpha_{1}$ & -1.4574 & 0.9082 & 0.1103 & CAS & $\alpha_{1}$ & 5.0082 & 1.2489 & 0.0001 \\
\hline IOP & $\alpha_{2}$ & 0.5851 & 8.9677 & 0.9481 & MEM & $\alpha_{2}$ & 30.6483 & 11.6216 & 0.0091 \\
\hline DEF & $\alpha_{3}$ & -28.7158 & 122.1786 & 0.8145 & CNT & $\alpha_{3}$ & 15.3724 & 15.7031 & 0.3290 \\
\hline FIV & $\alpha_{4}$ & -1725.1990 & 1508.0080 & 0.2542 & RLL & $\alpha_{4}$ & -15.3239 & 22.1377 & 0.4897 \\
\hline $.5 \times \mathrm{CAS}^{2}$ & $\beta_{1}$ & 0.0000 & 0.0000 & 0.1951 & $.5 \times \mathrm{CAS}^{2}$ & $\beta_{1}$ & 0.0007 & 0.0004 & 0.1305 \\
\hline $.5 \times 10 P^{2}$ & $\beta_{2}$ & -0.0004 & 0.0156 & 0.9807 & $.5 \times \mathrm{MEM}^{2}$ & $\beta_{2}$ & -0.0194 & 0.0149 & 0.1942 \\
\hline $.5 \times \mathrm{DEF}^{2}$ & $\beta_{3}$ & 0.6318 & 1.8871 & 0.7382 & $.5 \times \mathrm{CNT}^{2}$ & $\beta_{3}$ & -0.0407 & 0.0397 & 0.3065 \\
\hline $.5 \times \mathrm{FIV}^{2}$ & $\beta_{4}$ & 380.0642 & 466.0736 & 0.4159 & $.5 \times \mathrm{RLL}^{2}$ & $\beta_{4}$ & -0.1497 & 0.0790 & 0.0599 \\
\hline CAS $\times I O P$ & $\delta_{12}$ & 0.0022 & 0.0015 & 0.1426 & CAS $\times M E M$ & $\delta_{12}$ & -0.0087 & 0.0048 & 0.0705 \\
\hline $\mathrm{CAS} \times \mathrm{DEF}$ & $\delta_{13}$ & 0.0090 & 0.0067 & 0.1834 & $\mathrm{CAS} \times \mathrm{CNT}$ & $\delta_{13}$ & -0.0062 & 0.0039 & 0.1074 \\
\hline CAS $\times$ FIV & $\delta_{14}$ & 0.8976 & 0.1105 & 0.0000 & $\mathrm{CAS} \times \mathrm{RLL}$ & $\delta_{14}$ & 0.0046 & 0.0024 & 0.0560 \\
\hline $\mathrm{IOP} \times \mathrm{DEF}$ & $\delta_{23}$ & 0.0589 & 0.1394 & 0.6731 & $\mathrm{MEM} \times \mathrm{CNT}$ & $\delta_{23}$ & 0.1169 & 0.0465 & 0.0129 \\
\hline IOP $\times$ FIV & $\delta_{24}$ & -1.9881 & 6.6670 & 0.7659 & $M E M \times R L L$ & $\delta_{24}$ & -0.0160 & 0.0460 & 0.7280 \\
\hline DEF $\times$ FIV & $\delta_{34}$ & -9.5886 & 19.4821 & 0.6232 & $\mathrm{CNT} \times \mathrm{RLL}$ & $\delta_{34}$ & 0.0743 & 0.0465 & 0.1118 \\
\hline
\end{tabular}


Table 3: Marginal and average incremental costs

\begin{tabular}{|c|c|c|c|c|c|c|c|c|c|}
\hline & \multirow[b]{2}{*}{ Level } & \multicolumn{4}{|c|}{ Investment costs } & \multicolumn{4}{|c|}{ Operating costs } \\
\hline & & CAS & IOP & DEF & FIV & CAS & MEM & CNT & RLL \\
\hline \multirow{10}{*}{ 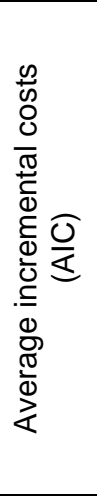 } & $50 \%$ & 0.3576 & 2.5098 & 0.0000 & 0.0000 & 0.3577 & 26.0977 & 12.5012 & 109.1305 \\
\hline & $75 \%$ & 1.2650 & 3.4721 & 0.0000 & 554.9150 & 0.0365 & 23.8224 & 11.0655 & 96.5980 \\
\hline & $100 \%$ & 2.1725 & 4.4344 & 0.0000 & 1314.9530 & 0.0000 & 21.5471 & 9.6299 & 84.0655 \\
\hline & $125 \%$ & 3.0800 & 5.3967 & 0.0000 & 2074.9910 & 0.0000 & 19.2719 & 8.1943 & 71.5330 \\
\hline & $150 \%$ & 3.9875 & 6.3591 & 1.8424 & 2835.0290 & 0.0000 & 16.9966 & 6.7587 & 59.0006 \\
\hline & $175 \%$ & 4.8950 & 7.3214 & 6.9354 & 3595.0670 & 0.0000 & 14.7213 & 5.3230 & 46.4681 \\
\hline & $200 \%$ & 5.8025 & 8.2837 & 12.0284 & 4355.1050 & 0.0000 & 12.4460 & 3.8874 & 33.9356 \\
\hline & $225 \%$ & 6.7100 & 9.2460 & 17.1215 & 5115.1430 & 0.0000 & 10.1707 & 2.4518 & 21.4031 \\
\hline & $250 \%$ & 7.6175 & 10.2084 & 22.2145 & 5875.1810 & 0.0000 & 7.8954 & 1.0162 & 8.8707 \\
\hline & $300 \%$ & 9.4325 & 12.1330 & 32.4006 & 7395.2570 & 0.0000 & 3.3449 & 0.0000 & 0.0000 \\
\hline \multirow{10}{*}{ 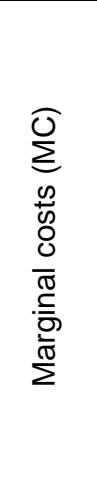 } & $50 \%$ & 3.6300 & 3.8493 & 20.3618 & 3040.1520 & 0.0000 & 4.3413 & 1.0355 & 16.4395 \\
\hline & $75 \%$ & 3.5920 & 3.8401 & 28.4717 & 3361.0700 & 0.0000 & 0.0000 & 0.0000 & 20.3637 \\
\hline & $100 \%$ & 3.5541 & 3.8310 & 36.5815 & 3681.9881 & 0.0000 & 0.0000 & 0.0000 & 24.2879 \\
\hline & $125 \%$ & 3.5161 & 3.8218 & 44.6914 & 4002.9061 & 0.4545 & 0.0000 & 0.0000 & 28.2121 \\
\hline & $150 \%$ & 3.4781 & 3.8127 & 52.8012 & 4323.8242 & 1.0343 & 0.0000 & 0.0000 & 32.1363 \\
\hline & $175 \%$ & 3.4402 & 3.8035 & 60.9111 & 4644.7422 & 1.6140 & 0.0000 & 0.0000 & 36.0605 \\
\hline & $200 \%$ & 3.4022 & 3.7944 & 69.0209 & 4965.6602 & 2.1937 & 0.0000 & 0.0000 & 39.9847 \\
\hline & $225 \%$ & 3.3643 & 3.7852 & 77.1307 & 5286.5783 & 2.7735 & 0.0000 & 0.0000 & 43.9089 \\
\hline & $250 \%$ & 3.3263 & 3.7761 & 85.2406 & 5607.4963 & 3.3532 & 0.0000 & 0.0000 & 47.8331 \\
\hline & $300 \%$ & 3.2504 & 3.7577 & 101.4603 & 6249.3324 & 4.5127 & 0.0000 & 0.0000 & 55.6814 \\
\hline
\end{tabular}


Table 4: Economies of scale and scope

\begin{tabular}{|c|c|c|c|c|c|c|c|c|c|c|c|}
\hline & \multirow[b]{2}{*}{ Level } & \multicolumn{5}{|c|}{ Investment costs } & \multicolumn{5}{|c|}{ Operating costs } \\
\hline & & $\mathrm{E}(\mathrm{CAS})$ & $E(I O P)$ & $E(D E F)$ & $E(F I V)$ & $\mathrm{E}(\mathrm{RAY})$ & $\mathrm{E}(\mathrm{CAS})$ & $\mathrm{E}(\mathrm{MEM})$ & $\mathrm{E}(\mathrm{CNT})$ & $\mathrm{E}(\mathrm{RLL})$ & $\mathrm{E}(\mathrm{RAY})$ \\
\hline \multirow{11}{*}{ 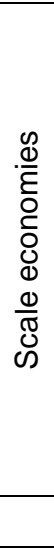 } & $50 \%$ & 0.0985 & 0.6520 & 0.0000 & 0.0000 & $4 \quad 3.2737$ & \multirow{2}{*}{$\begin{array}{l}0.0000 \\
0.0000\end{array}$} & 1 6.0115 & A 12.0729 & 6.6383 & 4 2.7133 \\
\hline & $75 \%$ & 0.3522 & 0.9042 & 0.0000 & 0.1651 & 2.6778 & & 0.0000 & 0.0000 & 4.7436 & 2.5680 \\
\hline & $100 \%$ & 0.6113 & 4 1.1575 & 0.0000 & 0.3571 & 2.9277 & 1 2.2737 & 0.0000 & 0.0000 & 3.4612 & 2.4396 \\
\hline & $125 \%$ & 0.8760 & 1.4121 & 0.0000 & 0.5184 & 3.5160 & 0.0000 & 0.0000 & 0.0000 & 2.5355 & 2.3179 \\
\hline & $150 \%$ & 千 1.1465 & 1.6679 & 0.0349 & 0.6557 & 4.2735 & 0.0000 & 0.0000 & 0.0000 & 1.8359 & 2.1996 \\
\hline & $175 \%$ & 1.4229 & 1.9249 & 0.1139 & 0.7740 & 5.1277 & 0.0000 & 0.0000 & 0.0000 & 1.2886 & 2.0832 \\
\hline & $200 \%$ & 1.7055 & 2.1832 & 0.1743 & 0.8770 & 6.0423 & 0.0000 & 0.0000 & 0.0000 & 0.8487 & 1.9680 \\
\hline & $225 \%$ & 1.9945 & 2.4427 & 0.2220 & 0.9676 & 6.9972 & 0.0000 & 0.0000 & 0.0000 & 0.4874 & 1.8537 \\
\hline & $250 \%$ & 2.2901 & 2.7034 & 0.2606 & 4 1.0477 & 7.9802 & 0.0000 & 0.0000 & 0.0000 & 0.1855 & 1.7399 \\
\hline & $300 \%$ & $\downarrow \quad 2.9020$ & $\downarrow \quad 3.2288$ & 0.3193 & $\downarrow \quad 1.1834$ & 10.0027 & 0.0000 & 0.0000 & 0.0353 & 0.0000 & 1.5134 \\
\hline & Level & PSE(CAS) & PSE(IOP) & PSE(DEF) & PSE(FIV) & GES & PSE(CAS) & PSE(MEM) & $\mathrm{PSE}(\mathrm{CNT})$ & PSE(RLL) & GES \\
\hline & $50 \%$ & 0.9165 & 4 1.5316 & T 1.5398 & I 1.1471 & $\begin{array}{l}\mathbf{4} \\
\end{array}$ & 0.4440 & 0.0941 & 0.0542 & 0.0542 & 0.6231 \\
\hline & $75 \%$ & 0.1013 & $\downarrow \quad 1.2293$ & $\downarrow \quad 1.2442$ & 0.5241 & 2.8130 & 0.6708 & 0.1162 & 0.0530 & 0.0530 & 0.7194 \\
\hline & $100 \%$ & 0.0000 & 0.8249 & 0.8431 & 0.0000 & 1.4080 & 0.9253 & 0.1470 & 0.0583 & 0.0583 & 0.8423 \\
\hline 言 & $125 \%$ & 0.0000 & 0.5339 & 0.5528 & 0.0000 & 0.4911 & 1.2076 & 0.1835 & 0.0669 & 0.0669 & 0.9847 \\
\hline రั & $150 \%$ & 0.0000 & 0.3529 & 0.3715 & 0.0000 & 0.0000 & 1.5203 & 0.2253 & 0.0778 & 0.0778 & 1.1458 \\
\hline $\begin{array}{l}0 \\
0 \\
0\end{array}$ & $175 \%$ & 0.0000 & 0.2410 & 0.2591 & 0.0000 & 0.0000 & 1.8677 & 0.2725 & 0.0908 & 0.0908 & 1.3267 \\
\hline 응 & $200 \%$ & 0.0000 & 0.1695 & 0.1870 & 0.0000 & 0.0000 & 2.2555 & 0.3258 & 0.1060 & 0.1060 & 1.5299 \\
\hline œ & $225 \%$ & 0.0000 & 0.1218 & 0.1389 & 0.0000 & 0.0000 & 2.6907 & 0.3859 & 0.1233 & 0.1233 & 1.7589 \\
\hline & $250 \%$ & 0.0000 & 0.0888 & 0.1055 & 0.0000 & 0.0000 & 3.1825 & 0.4541 & 0.1433 & 0.1433 & 2.0184 \\
\hline & $300 \%$ & 0.0000 & 0.0478 & 0.0638 & 0.0000 & 0.0000 & 4.3856 & 0.6215 & 0.1928 & 0.1928 & 2.6547 \\
\hline
\end{tabular}

Notes: Arrows indicate the range over which economies of scale (scope) are found. 